\title{
PENGARUH SUHU DAN LAMA PENGERINGAN TERHADAP KARAKTERISTIK TEH BUNGA TELANG (Clitoria ternatea L.)
}

\author{
The Effect of Drying Temperature and Time on The Characteristics of Blue Pea Flower \\ Tea (Clitoria ternatea $\mathrm{L}$. \\ ${ }^{1}$ Ni Ketut Ayu Martini, ${ }^{2}$ I Gusti Ayu Ekawati*, ${ }^{2}$ Putu Timur Ina \\ ${ }^{1}$ Mahasiswa Program Studi Ilmu dan Teknologi Pangan, Fakultas Teknologi Pertanian, Unud \\ ${ }^{2}$ Dosen Program Studi Ilmu dan Teknologi Pangan, Fakultas Teknologi Pertanian, Unud \\ Kampus Bukit Jimbaran, Badung-Bali
}

\begin{abstract}
This study was conducted to determine the effect of drying temperature and time on the characteristics of blue pea flower tea and obtain drying temperature and time that produce blue pea flower tea with the best characteristics. The experimental design used was a factorial Randomize Block Design consisting of 2 factors: the first factor was drying temperature, namely $50^{\circ} \mathrm{C}, 60^{\circ} \mathrm{C}$, and $70^{\circ} \mathrm{C}$ and the second factor was drying time, namely 3 hours, 3.5 hours, and 4 hours. The treatment was repeated 2 times to obtain 18 experimental units. The data obtained were analyzed by analysis of variance (ANOVA) and if the treatment had significant effect followed by Duncan test. The results showed that interaction between drying temperature and time had a significant effect on water content, extract content, total phenol, flavonoids, anthocyanin, and antioxidant activity. Drying at a temperature of $50^{\circ} \mathrm{C}$ for 4 hours was produced blue pea flower tea with the highest antioxidant activity $\left(\mathrm{IC}_{50}\right)$ of $128.25 \mathrm{ppm}$, water content of $10.18 \%$, extract content of $51.60 \%$, total phenol of $515.48 \mathrm{mg} / 100 \mathrm{~g}$, flavonoids of $23.99 \mathrm{mg} / 100 \mathrm{~g}$, and anthocyanin of $249.69 \mathrm{mg} / 100 \mathrm{~g}$.
\end{abstract}

Keywords: telang flower, drying temperature, drying time, herbal tea

\section{PENDAHULUAN}

Teh herbal adalah minuman yang dibuat menggunakan bahan selain dari daun teh (Camellia sinensis) yaitu dengan bebungaan, bebijian, dedaunan, atau akar dari berbagai tanaman lain (Yudhana, 2004 dalam kusumaningrum, 2013). Penelitian mengenai teh herbal sudah banyak dilakukan seperti pada penelitian Rohkyani (2015) tentang pengolahan teh herbal bunga kecombrang dan penelitian Rindy (2017) tentang pengolahan teh herbal daun binahong. Selain bahan tersebut, terdapat salah satu tanaman yang juga dapat diolah menjadi teh herbal dan belum ada penelitian

*Korespondensi penulis:

Email: ayuekawati@unud.ac.id terkait bahan tersebut, yaitu bunga telang (Clitoria ternatea $\mathrm{L}$.).

\section{Bunga telang (Clitoria ternatea L.)} sering disebut juga sebagai butterfly pea atau blue pea merupakan bunga yang khas dengan kelopak tunggal berwarna ungu, biru, merah muda (pink) dan putih (Budiasih, 2017). Tanaman telang tumbuh baik pada berbagai kisaran jenis tanah, toleran terhadap kelebihan hujan maupun kekeringan. Faktor inilah yang menjadikan bunga telang mudah ditemui di Indonesia dan menyebar ke negara-negara beriklim tropis dan subtropis (Alnanda et al., 2017). Pemanfaatan bunga telang dalam bidang pangan telah dilakukan di beberapa negara, 
seperti pengobatan tradisional di Kerala India, sebagai sayuran segar di Filipina, pewarna beras ketan di Malaysia, dan minuman herbal di Thailand (Lee et al., 2011).

Di Indonesia, bunga telang belum banyak dimanfaatkan. Penggunaan bunga telang selama ini hanya terbatas sebagai bahan pembuatan pupuk dan pakan ternak (Parwata et al., 2016) serta sebagai pewarna alami pada makanan (Alnanda et al., 2017). Menurut Budiasih (2017), bunga telang mengandung tanin, flobatanin, karbohidrat, saponin, triterpenoid, polifenol, flavanol glikosida, protein, alkaloid, antrakuinon, antosianin, stigmasit 4-ena-3,6 dion, minyak volatil dan steroid. Bunga telang memiliki banyak potensi farmakologis antara lain sebagai antioksidan, antibakteri, antiparasit dan antisida, antidiabetes, dan anti-kanker. Kandungan fitokimia dalam bunga telang tersebut menunjukkan bahwa bunga telang memiliki potensi untuk diolah menjadi teh herbal.

Menurut Adri dan Hersoelistyorini (2013), cara dalam pengolahan teh herbal yang dikeringkan sama dengan cara pengolahan teh kering pada umumnya meliputi pemetikan, pencucian, pelayuan, dan pengeringan. Salah satu faktor yang mempengaruhi kualitas teh herbal adalah suhu dan lama waktu pengeringan. Penggunaan suhu yang terlalu tinggi dan waktu pengeringan yang terlalu lama dapat menyebabkan terjadinya perubahan beberapa karakteristik pada bahan seperti kerusakan senyawa antioksidan (Hartiati $e t$ al., 2009). Hal ini diperkuat oleh penelitian yang dilakukan oleh Muawanah (2012) pemanasan dapat mempercepat oksidasi antioksidan sehingga mengakibatkan penurunan aktivitas antioksidan pada bahan. Sedangkan suhu yang terlalu rendah dan waktu pengeringan yang terlalu singkat dapat mengakibatkan produk yang dihasilkan mudah rusak akibat kandungan air yang tinggi. Penelitian ini bertujuan untuk mengetahui pengaruh suhu dan lama waktu pengeringan terhadap karakteristik teh herbal bunga telang dan mendapatkan suhu dan lama waktu pengeringan yang tepat sehingga dihasilkan teh herbal bunga telang dengan karakteristik terbaik.

\section{METODE PENELITIAN}

\section{Tempat dan Waktu}

Penelitian ini dilaksanakan di

Laboratorium Analisis Pangan dan Laboratorium Pengolahan Pangan Program Studi Ilmu dan Teknologi Pangan Fakultas Teknologi Pertanian Universitas Udayana, Kampus Sudirman. Pelaksanaan penelitian ini dilakukan pada bulan Juli 2019 sampai September 2019.

\section{Bahan dan Alat}

Bahan yang digunakan dalam penelitian ini adalah bunga telang biru double petals yang didapat dari Desa Penarukan, Kerambitan, Tabanan. Bahan kimia yang digunakan antara lain: aquades, 
standar asam galat, $\mathrm{Na}_{2} \mathrm{CO}_{3}$, reagen FolinCiocalteau (Merck), methanol, standar Quersetin, $\mathrm{NaNO}_{2}, \mathrm{AlCl}_{3}, \mathrm{NaOH}, \mathrm{HCl}$, Larutan Buffer $\mathrm{pH}$ 1, Buffer $\mathrm{pH}$ 4.5, Diphenylpicryl-hydrazyl (DPPH).

Alat-alat yang dipergunakan dalam penelitian ini adalah oven (Merck), loyang, gunting, aluminium foil, pinset, timbangan analitik (Shimadzu), cawan aluminium, cawan porselin, labu ukur, penangas air, kompor listrik, gelas beker (Pyrex), gelas ukur (Herma), tabung reaksi (Pyrex), pipet tetes, blender (Miyako), spektrofotometer (Thermo Scientific Genesys 10S UV-Vis), mikropipet (Socorex), desikator, erlenmeyer (Pyrex), kuvet (Pyrex), pompa karet, tip, kertas saring, vortex (Maxi Mix II Type 367000), ayakan 40 mesh, dan gelas untuk uji sensoris.

\section{Rancangan Percobaan}

Rancangan percobaan yang digunakan dalam penelitian ini adalah Rancangan Acak Kelompok (RAK) pola faktorial yang terdiri dari 2 faktor yaitu faktor pertama adalah perlakuan suhu $(\mathrm{T})$ yang terdiri dari 3 taraf yaitu $\mathrm{T}_{1}\left(50^{\circ} \mathrm{C}\right), \mathrm{T}_{2}\left(60^{\circ} \mathrm{C}\right)$, dan $\mathrm{T}_{3}\left(70^{\circ} \mathrm{C}\right)$ dan faktor kedua adalah perlakuan lama pengeringan (W) yang terdiri dari 3 taraf yaitu $\mathrm{W}_{1}(3 \mathrm{jam}), \mathrm{W}_{2}(3,5 \mathrm{jam})$, dan $\mathrm{W}_{3}$ (4 jam). Masing-masing perlakuan dilakukan ulangan sebanyak 2 kali sehingga diperoleh 18 unit percobaan. Faktor kombinasi perlakuan adalah sebagai berikut:

$\mathrm{T}_{1} \mathrm{~W}_{1}=$ Suhu $50^{\circ} \mathrm{C}$, lama $3 \mathrm{jam}$
$\mathrm{T}_{1} \mathrm{~W}_{2}=$ Suhu $50^{\circ} \mathrm{C}$, lama $3,5 \mathrm{jam}$

$\mathrm{T}_{1} \mathrm{~W}_{3}=$ Suhu $50^{\circ} \mathrm{C}$, lama 4 jam

$\mathrm{T}_{2} \mathrm{~W}_{1}=$ Suhu $60^{\circ} \mathrm{C}$, lama $3 \mathrm{jam}$

$\mathrm{T}_{2} \mathrm{~W}_{2}=$ Suhu $60^{\circ} \mathrm{C}$, lama 3,5 jam

$\mathrm{T}_{2} \mathrm{~W}_{3}=$ Suhu $60^{\circ} \mathrm{C}$, lama $4 \mathrm{jam}$

$\mathrm{T}_{3} \mathrm{~W}_{1}=$ Suhu $70^{\circ} \mathrm{C}$, lama $3 \mathrm{jam}$

$\mathrm{T}_{3} \mathrm{~W}_{2}=$ Suhu $70^{\circ} \mathrm{C}$, lama 3,5 jam

$\mathrm{T}_{3} \mathrm{~W}_{3}=$ Suhu $70^{\circ} \mathrm{C}$, lama 4 jam

Variabel yang diamati dalam penelitian ini meliputi kadar air (Sudarmadji, 1997), kadar sari, total fenol, total flavonoid (Rohman, 2006), total antosianin (Giusti, 2001), dan aktivitas antioksidan $\left(\mathrm{IC}_{50}\right)$ terhadap bubuk teh bunga telang. Selain variabel tersebut, juga dilakukan uji warna dengan color reader dan uji sensoris meliputi uji hedonik warna, aroma, rasa, penerimaan keseluruhan, dan skoring rasa menggunakan seduhan teh herbal bunga telang yang dibuat dengan cara bubuk teh dimasukkan kedalam kantong teh celup sebanyak $1 \mathrm{~g}$ dan diseduh dengan cara dicelup dalam $250 \mathrm{ml}$ air dengan suhu $100^{\circ} \mathrm{C}$ selama 2 menit (Dewata, 2017 yang dimodifikasi).

Data yang diperoleh dianalisis dengan sidik ragam dan apabila perlakuan berpengaruh terhadap variabel yang diamati maka dilanjutkan dengan uji Duncan. Data hasil uji sensoris dianalisis menggunakan Rancangan Acak Kelompok (RAK) meliputi sidik ragam dan uji Duncan apabila perlakuan berpengaruh terhadap variabel yang diamati (Gomez dan Gomez, 1995). 


\section{Pelaksanaan Penelitian}

Pelaksanaan penelitian meliputi beberapa tahap sebagai berikut.

1. Persiapan Bahan Baku

Bunga telang segar disiapkan kemudian dilanjutkan dengan sortasi bahan baku dengan memilih bunga telang yang memiliki warna biru cerah dan tidak rusak. Bunga telang dicuci dengan air mengalir untuk membersihkan debu atau kotoran yang menempel pada permukaan bunga. Bunga telang yang sudah bersih kemudian dipisahkan antara kuntum dengan tangkai bunga. Bahan yang digunakan pada masingmasing perlakuan adalah $200 \mathrm{~g}$.

\section{Pelayuan}

Dilakukan pada suhu ruang selama 8 jam, dengan cara kuntum bunga telang dipaparkan di atas jaring lapis tipis, dan dibalik sebanyak 3 kali agar pelayuan terjadi secara merata antara permukaan atas dan permukaan bawah bunga.

3. Pengeringan

Pengeringan dilakukan dengan suhu $50^{\circ} \mathrm{C}, 60^{\circ} \mathrm{C}$, dan $70^{\circ} \mathrm{C}$ selama 3 jam, 3,5 jam, dan 4 jam. Bunga telang yang sudah dikeringkan kemudian dihancurkan dengan blender dan dilakukan pengayakan mengguna-kan ayakan 40 mesh. Diagram alir pembuatan teh herbal bunga telang dapat dilihat pada Gambar 1.

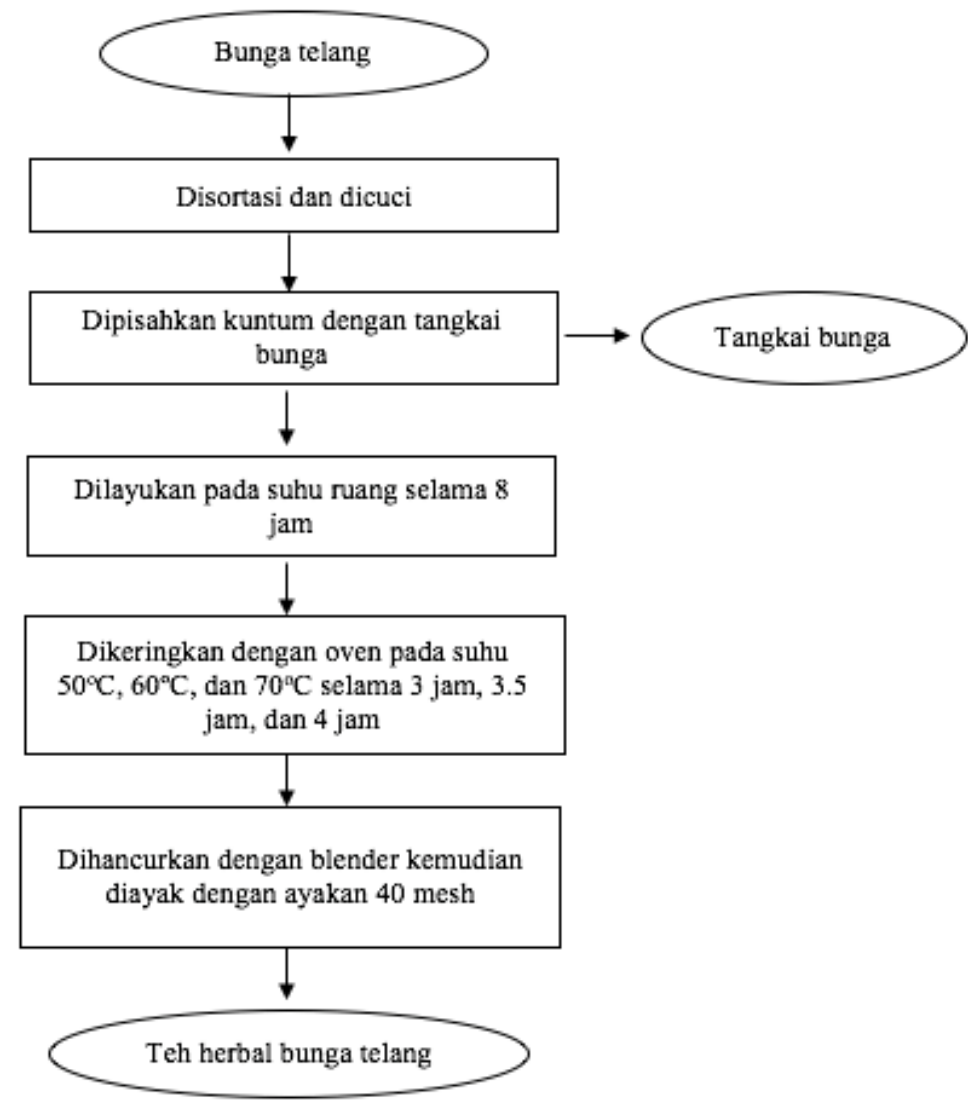

Gambar 1. Diagram alir pembuatan teh herbal bunga telang (Kusuma et al., 2019), yang dimodifikasi. 
HASIL DAN PEMBAHASAN Kadar air teh herbal bunga telang
Nilai rata-rata kadar air teh herbal bunga telang dapat dilihat pada Tabel 1.

Tabel 1. Nilai rata-rata kadar air teh herbal bunga telang

\begin{tabular}{cccc}
\hline \multirow{2}{*}{ Suhu Pengeringan (T) } & \multicolumn{3}{c}{ Lama Pengeringan (W) } \\
& 3 jam (W1) & 3,5 jam (W2) & 4 jam (W3) \\
\hline \multirow{2}{*}{$50^{\circ} \mathrm{C}(\mathrm{T} 1)$} & $11,66 \mathrm{C}$ & $10,94 \mathrm{C}$ & $10,18 \mathrm{C}$ \\
& $\mathrm{c}$ & $\mathrm{b}$ & $\mathrm{a}$ \\
$60^{\circ} \mathrm{C}(\mathrm{T} 2)$ & $9,91 \mathrm{~B}$ & $9,36 \mathrm{~B}$ & $8,58 \mathrm{~B}$ \\
& $\mathrm{c}$ & $\mathrm{b}$ & $\mathrm{a}$ \\
$70^{\circ} \mathrm{C}(\mathrm{T} 3)$ & $8,37 \mathrm{~A}$ & $8,06 \mathrm{~A}$ & $7,73 \mathrm{~A}$ \\
& $\mathrm{c}$ & $\mathrm{b}$ & $\mathrm{a}$ \\
\hline
\end{tabular}

Keterangan: - Nilai rata-rata yang diikuti huruf yang sama pada kolom yang sama menunjukkan berbeda tidak nyata $(\mathrm{p}>0,05)$.

- Nilai rata-rata yang diikuti huruf yang sama pada baris yang sama menunjukkan berbeda tidak nyata $(\mathrm{p}>0,05)$.

Hasil sidik ragam menunjukkan bahwa perlakuan interaksi antara suhu dan lama waktu pengeringan berpengaruh sangat nyata $(\mathrm{P}<0,01)$ terhadap kadar air teh herbal bunga telang. Tabel 1 menunjukkan kadar air tertinggi teh herbal bunga telang diperoleh pada perlakuan T1W1 (suhu pengeringan $50^{\circ} \mathrm{C}$ dan lama waktu 3 jam) yaitu $11,66 \%$, sedangkan kadar air terendah teh herbal bunga telang diperoleh pada perlakuan $\mathrm{T} 3 \mathrm{~W} 3$ (suhu pengeringan $70^{\circ} \mathrm{C}$ dan lama waktu pengeringan 4 jam) yaitu 7,73\%. Hal ini menunjukkan semakin tinggi suhu dan lama pengeringan maka kadar air teh herbal bunga telang yang dihasilkan semakin kecil. Menurut Karina (2008), semakin tinggi suhu selama proses pengeringan, maka semakin besar energi panas yang dibawa udara sehingga makin banyak jumlah massa cairan yang diuapkan dari permukaan bahan yang dikeringkan. Proses pengeringan dengan waktu yang bervariasi menyebabkan penguapan kadar air yang berbeda. Semakin lama waktu pengeringan yang dilakukan, maka panas yang diterima oleh bahan akan lebih lama sehingga jumlah air yang diuapkan dalam bahan pangan tersebut semakin banyak, dan kadar air yang terukur menjadi rendah (Dwi, 2016). Hal ini sesuai dengan penelitian yang dilakukan oleh Fitrayana (2014), bahwa kadar air teh herbal daun pare semakin menurun pada suhu dan lama waktu pengeringan yang semakin tinggi. Berdasarkan SNI: (01-7085-2005) tentang bubuk simplisia, kadar air untuk simplisia adalah maksimal $10 \%$. Hasil penelitian menunjukkan semua perlakuan sesuai dengan SNI kecuali pada perlakuan T1W1 dan T1W2.

\section{Kadar sari teh herbal bunga telang}

Nilai rata-rata kadar sari teh herbal bunga telang dapat dilihat pada Tabel 2. 
Tabel 2. Nilai rata-rata kadar sari teh herbal bunga telang

\begin{tabular}{cccc}
\hline \multirow{2}{*}{ Suhu Pengeringan (T) } & \multicolumn{3}{c}{ Lama Pengeringan (W) } \\
& 3 jam (W1) & 3,5 jam (W2) & 4 jam (W3) \\
\hline \multirow{2}{*}{$50^{\circ} \mathrm{C}(\mathrm{T} 1)$} & $46,47 \mathrm{~A}$ & $47,46 \mathrm{~A}$ & $51,60 \mathrm{~A}$ \\
& $\mathrm{a}$ & $\mathrm{a}$ & $\mathrm{b}$ \\
$60^{\circ} \mathrm{C}(\mathrm{T} 2)$ & $52,42 \mathrm{~B}$ & $52,59 \mathrm{~B}$ & $53,22 \mathrm{~A}$ \\
& $\mathrm{a}$ & $\mathrm{a}$ & $\mathrm{a}$ \\
$70^{\circ} \mathrm{C}(\mathrm{T} 3)$ & $53,94 \mathrm{~B}$ & $55,18 \mathrm{C}$ & $56,07 \mathrm{~B}$ \\
& $\mathrm{a}$ & $\mathrm{ab}$ & $\mathrm{b}$ \\
\hline
\end{tabular}

Keterangan : - Nilai rata-rata yang diikuti huruf yang sama pada kolom yang sama menunjukkan berbeda tidak nyata $(\mathrm{p}>0,05)$.

- Nilai rata-rata yang diikuti huruf yang sama pada baris yang sama menunjukkan berbeda tidak nyata $(\mathrm{p}>0,05)$.

Hasil sidik ragam menunjukkan bahwa interaksi antara suhu dan lama waktu pengeringan berpengaruh sangat nyata $(\mathrm{P}<0,01)$ terhadap kadar sari teh herbal bunga telang. Tabel 2 menunjukkan kadar sari teh herbal bunga telang berkisar antara 46,47\% sampai dengan $56,07 \%$. Kadar sari teh herbal bunga telang terendah diperoleh pada perlakuan T1W1 (suhu pengeringan $50^{\circ} \mathrm{C}$ dan lama waktu 3 jam) yaitu $46,47 \%$ tidak berbeda nyata dengan T1W2, sedangkan kadar sari teh herbal bunga telang tertinggi diperoleh pada perlakuan T3W3 (suhu pengeringan $70^{\circ} \mathrm{C}$ dan lama waktu 4 jam) yaitu 56,07\% dan tidak berbeda nyata dengan perlakuan T3W2.

Menurut Dwi (2016), kadar sari merupakan istilah yang digunakan untuk menggambarkan partikel-partikel pada minuman teh herbal yang dapat larut didalam air seduhan. Hasil penelitian menunjukkan bahwa semakin tinggi suhu dan lama waktu pengeringan maka kadar sari juga semakin meningkat. Hal ini disebabkan suhu pengeringan yang tinggi dan waktu yang semakin lama menghasilkan kadar air yang rendah yang mengakibatkan bubuk menjadi lebih higroskopis dan mudah menyerap air sehingga kelarutan bubuk dalam air juga semakin besar (Purnomo, 2016 dalam Kusuma et al., 2019). Hal ini sesuai dengan penelitian yang dilakukan oleh Kusuma et al. (2019) tentang pengaruh suhu pengeringan terhadap karakteristik teh herbal kulit kakao bahwa semakin tinggi suhu pengeringan, akan mendapatkan kadar sari yang tinggi. Demikian juga dengan penelitian Siti et al. (2018) tentang pengaruh lama pengeringan terhadap karakteristik teh herbal kulit melinjo menghasilkan kadar sari yang semakin tinggi pada pengeringan yang semakin lama. Berdasarkan SNI : (01-70852005) tentang bubuk simplisia, kadar sari untuk bubuk simplisia adalah minimal $14 \%$. Data pada Tabel 2 menunjukkan hasil yang diperoleh dari penelitian ini telah memenuhi SNI bubuk simplisia. 
Total fenol the herbal bunga telang

Nilai rata-rata total fenol teh herbal bunga telang dapat dilihat pada Tabel 3. Hasil sidik ragam menunjukkan bahwa interaksi antara suhu dan lama waktu pengeringan berpengaruh sangat nyata $(\mathrm{P}<0,01)$ terhadap kandungan total fenol teh herbal bunga telang.

Tabel 3. Nilai rata-rata total fenol teh herbal bunga telang

\begin{tabular}{cccc}
\hline \multirow{2}{*}{ Suhu Pengeringan (T) } & \multicolumn{3}{c}{ Lama Pengeringan (W) } \\
& 3 jam (W1) & 3,5 jam (W2) & 4 jam (W3) \\
\hline \multirow{2}{*}{$50^{\circ} \mathrm{C}(\mathrm{T} 1)$} & $464,10 \mathrm{~B}$ & $477,74 \mathrm{~B}$ & $515,48 \mathrm{C}$ \\
& $\mathrm{a}$ & $\mathrm{ab}$ & $\mathrm{b}$ \\
$60^{\circ} \mathrm{C}(\mathrm{T} 2)$ & $489,35 \mathrm{C}$ & $459,31 \mathrm{~B}$ & $440,81 \mathrm{~B}$ \\
& $\mathrm{c}$ & $\mathrm{b}$ & $\mathrm{a}$ \\
$70^{\circ} \mathrm{C}(\mathrm{T} 3)$ & $408,85 \mathrm{~A}$ & $400,54 \mathrm{~A}$ & $263,75 \mathrm{~A}$ \\
& $\mathrm{~b}$ & $\mathrm{~b}$ & $\mathrm{a}$ \\
\hline
\end{tabular}

Keterangan : - Nilai rata-rata yang diikuti huruf yang sama pada kolom yang sama menunjukkan berbeda tidak nyata $(\mathrm{p}>0,05)$.

- Nilai rata-rata yang diikuti huruf yang sama pada baris yang sama menunjukkan berbeda tidak nyata $(\mathrm{p}>0,05)$.

Nilai rata-rata total fenol tertinggi diperoleh pada perlakuan T1W3 (suhu pengeringan $50^{\circ} \mathrm{C}$ dan lama waktu 4 jam) yaitu $515,48 \mathrm{mg} / 100 \mathrm{~g}$ tidak berbeda nyata dengan T1W2, sedangkan nilai rata-rata terendah terdapat pada perlakuan T3W3 (suhu pengeringan $70^{\circ} \mathrm{C}$ dan lama waktu 4 jam) yaitu 263,75 mg/100g. Hasil penelitian menunjukkan suhu yang terlalu tinggi dan waktu pengeringan yang semakin lama menghasilkan total fenol yang semakin rendah, kecuali total fenol pada suhu $50^{\circ} \mathrm{C}$ dan waktu yang semakin lama (sampai 4 jam) menghasilkan total fenol yang lebih tinggi. Hal ini dapat disebabkan karena pada suhu yang rendah dan waktu yang singkat menyebabkan kandungan fenol yang terdapat dalam bahan tersebut belum terekstrak secara sempurna. Sedangkan pada suhu yang semakin tinggi dan waktu yang semakin lama mengakibatkan kandungan fenol dalam bahan mengalami kerusakan sehingga kadarnya menjadi semakin rendah. Hal ini sesuai dengan penelitian yang dilakukan oleh Rusnayanti (2018) bahwa suhu yang semakin tinggi dan waktu pengeringan yang semakin lama menghasilkan total fenol teh hijau daun kakao semakin rendah. Hal ini disebabkan oleh sifat senyawa fenol yang tidak tahan terhadap panas yang terlalu tinggi dan waktu pengeringan yang semakin lama mengakibatkan terjadinya waktu kontak bahan dengan panas semakin lama sehingga kesempatan panas untuk merusak komponen fenol meningkat.

\section{Total flavonoid teh herbal bunga telang}

Nilai rata-rata total flavonoid teh herbal bunga telang dapat dilihat pada Tabel 4 . 
Tabel 4. Nilai rata-rata total flavonoid teh herbal bunga telang

\begin{tabular}{cccc}
\hline \multirow{2}{*}{ Suhu Pengeringan (T) } & \multicolumn{3}{c}{ Lama Pengeringan (W) } \\
& 3 jam (W1) & 3,5 jam (W2) & 4 jam (W3) \\
\hline \multirow{2}{*}{$50^{\circ} \mathrm{C}(\mathrm{T} 1)$} & $18,71 \mathrm{~B}$ & $20,63 \mathrm{~B}$ & $23,99 \mathrm{C}$ \\
& $\mathrm{a}$ & $\mathrm{b}$ & $\mathrm{c}$ \\
$60^{\circ} \mathrm{C}(\mathrm{T} 2)$ & $22,51 \mathrm{C}$ & $17,50 \mathrm{~A}$ & $16,78 \mathrm{~B}$ \\
& $\mathrm{~b}$ & $\mathrm{a}$ & $\mathrm{a}$ \\
$70^{\circ} \mathrm{C}(\mathrm{T} 3)$ & $15,92 \mathrm{~A}$ & $16,47 \mathrm{~A}$ & $14,61 \mathrm{~A}$ \\
& $\mathrm{ab}$ & $\mathrm{b}$ & $\mathrm{a}$ \\
\hline
\end{tabular}

Keterangan : - Nilai rata-rata yang diikuti huruf yang sama pada kolom yang sama menunjukkan berbeda tidak nyata $(\mathrm{p}>0,05)$.

- Nilai rata-rata yang diikuti huruf yang sama pada baris yang sama menunjukkan berbeda tidak nyata $(\mathrm{p}>0,05)$.

Hasil sidik ragam menunjukkan bahwa interaksi antara suhu dan lama pengeringan berpengaruh sangat nyata $(\mathrm{P}<0,01)$ terhadap kandungan flavonoid teh herbal bunga telang. Nilai rata-rata total flavonoid tertinggi diperoleh pada perlakuan $\mathrm{T} 1 \mathrm{~W} 3$ (suhu pengeringan $50^{\circ} \mathrm{C}$ dan lama waktu 4 jam) yaitu $23,99 \mathrm{mg} / 100 \mathrm{~g}$. Adapun nilai rata-rata terendah terdapat pada perlakuan T3W3 (suhu pengeringan $70^{\circ} \mathrm{C}$ dan lama waktu 4 jam) yaitu 14,61 $\mathrm{mg} / 100 \mathrm{~g}$ tidak berbeda nyata dengan perlakuan T3W1. Hasil penelitian menunjukkan terjadi kecenderungan suhu yang terlalu tinggi dan waktu pengeringan yang semakin lama menghasilkan total flavonoid yang semakin rendah. Hal ini sesuai dengan penelitian yang dilakukan oleh Kusuma et al., (2019) bahwa suhu pengeringan yang tinggi dan waktu yang semakin lama menyebabkan kandungan flavonoid semakin rendah dikarenakan paparan panas dapat merusak beberapa komponen flavonoid dalam bahan.
Tabel 4 menunjukkan suhu $50^{\circ} \mathrm{C}$ dan waktu yang semakin lama yaitu 4 jam menghasilkan total flavonoid yang lebih tinggi dibandingkan pada waktu 3 dan 3,5 jam. Hal ini diduga karena pada suhu yang lebih rendah dan waktu yang singkat mengakibatkan komponen flavonoid dalam bahan belum terekstrak sempurna sehingga menghasilkan total flavonoid yang lebih rendah.

\section{Total antosianin teh herbal bunga telang}

Nilai rata-rata total antosianin teh herbal bunga telang dapat dilihat pada Tabel 5 . Hasil sidik ragam menunjukkan bahwa interaksi antara suhu dan lama waktu pengeringan berpengaruh sangat nyata $(\mathrm{P}<0,01)$ terhadap antosianin teh herbal bunga telang. Nilai rata-rata antosianin tertinggi diperoleh pada perlakuan T2W1 (suhu pengeringan $60^{\circ} \mathrm{C}$ dan lama waktu 3 jam) yaitu 264,11 mg/100g, sedangkan nilai rata-rata terendah terdapat pada perlakuan T3W3 (suhu pengeringan $70^{\circ} \mathrm{C}$ dan lama waktu 4 jam) yaitu $128,78 \mathrm{mg} / 100 \mathrm{~g}$. 
Tabel 5. Nilai rata-rata total antosianin teh herbal bunga telang

\begin{tabular}{cccc}
\hline \multirow{2}{*}{ Suhu Pengeringan (T) } & \multicolumn{3}{c}{ Lama Pengeringan (W) } \\
& 3 jam (W1) & 3,5 jam (W2) & 4 jam (W3) \\
\hline \multirow{2}{*}{$50^{\circ} \mathrm{C}(\mathrm{T} 1)$} & $224,03 \mathrm{~B}$ & $242,26 \mathrm{C}$ & $249,70 \mathrm{C}$ \\
& $\mathrm{a}$ & $\mathrm{b}$ & $\mathrm{b}$ \\
$60^{\circ} \mathrm{C}(\mathrm{T} 2)$ & $264,11 \mathrm{C}$ & $206,06 \mathrm{~B}$ & $203,85 \mathrm{~B}$ \\
& $\mathrm{~b}$ & $\mathrm{a}$ & $\mathrm{a}$ \\
$70^{\circ} \mathrm{C}(\mathrm{T} 3)$ & $196,39 \mathrm{~A}$ & $162,12 \mathrm{~A}$ & $128,78 \mathrm{~A}$ \\
& $\mathrm{c}$ & $\mathrm{b}$ & $\mathrm{a}$ \\
\hline
\end{tabular}

Keterangan : - Nilai rata-rata yang diikuti huruf yang sama pada kolom yang sama menunjukkan berbeda tidak nyata $(\mathrm{p}>0,05)$.

- Nilai rata-rata yang diikuti huruf yang sama pada baris yang sama menunjukkan berbeda tidak nyata $(p>0,05)$.

Suhu dan lama pengeringan dapat mempengaruhi total antosianin dalam suatu bahan. Suhu pengeringan yang disarankan dalam pengeringan adalah $50^{\circ} \mathrm{C}-60^{\circ} \mathrm{C}$. Hasil penelitian ini menunjukkan semakin tinggi suhu pengeringan dan waktu yang semakin lama menghasilkan nilai antosianin yang semakin rendah, kecuali perlakuan $\mathrm{T} 2 \mathrm{~W} 1$ (suhu pengeringan $60^{\circ} \mathrm{C}$ dan lama waktu 3 jam). Hal ini diduga karena pada suhu yeng terlalu rendah yaitu suhu $50^{\circ} \mathrm{C}$ pigmen warna antosianin belum terekstrak secara sempurna. Menurut Zussiva (2012) penggunaan suhu $60^{\circ} \mathrm{C}$ menghasilkan nilai antosianin yang lebih tinggi pada ekstrak bunga telang dibandingkan suhu yang lebih rendah. Suhu yang lebih tinggi mengakibatkan pori-pori padatan bunga telang semakin terbuka dan memudahkan pelarut untuk melarutkan antosianin sehingga dalam pengujian menghasilkan nilai absorbansi yang lebih besar. Namun pada suhu yang sama $\left(60^{\circ} \mathrm{C}\right)$ dan suhu lebih tinggi $\left(70^{\circ} \mathrm{C}\right)$ serta waktu yang semakin lama menghasilkan nilai antosianin yang semakin rendah. Hal ini menunjukkan suhu yang yang terlalu tinggi dan waktu yang semakin lama dapat menurunkan nilai antosianin teh herbal bunga telang. Menurut Markakis (1982) dalam Zussiza (2012) suhu pengeringan yang lebih tinggi dari $60^{\circ} \mathrm{C}$ mengakibatkan senyawa antosianin mengalami degradasi. Kerusakan akibat suhu tinggi tersebut terjadi karena terbukanya cincin aglikon sehingga terbentuk gugus karbinol dan kalkon yang tidak berwarna.

\section{Aktivitas antioksidan $\left(\mathrm{IC}_{50}\right)$ teh herbal bunga telang}

Nilai rata-rata aktivitas antioksidan teh herbal bunga telang dapat dilihat pada Tabel 6. 
Tabel 6. Nilai rata-rata aktivitas antioksidan teh herbal bunga telang

\begin{tabular}{cccc}
\hline \multirow{2}{*}{ Suhu Pengeringan (T) } & \multicolumn{3}{c}{ Lama Pengeringan (W) } \\
& 3 jam (W1) & 3,5 jam (W2) & 4 jam (W3) \\
\hline \multirow{2}{*}{$50^{\circ} \mathrm{C}(\mathrm{T} 1)$} & $169,61 \mathrm{~A}$ & $159,07 \mathrm{~A}$ & $128,25 \mathrm{~A}$ \\
& $\mathrm{~b}$ & $\mathrm{~b}$ & $\mathrm{a}$ \\
$60^{\circ} \mathrm{C}(\mathrm{T} 2)$ & $143,63 \mathrm{~A}$ & $153,22 \mathrm{~A}$ & $160,21 \mathrm{~B}$ \\
& $\mathrm{a}$ & $\mathrm{a}$ & $\mathrm{a}$ \\
$70^{\circ} \mathrm{C}(\mathrm{T} 3)$ & $170,08 \mathrm{~A}$ & $174,16 \mathrm{~A}$ & $174,38 \mathrm{C}$ \\
\hline
\end{tabular}

Keterangan : - Nilai rata-rata yang diikuti huruf yang sama pada kolom yang sama menunjukkan berbeda tidak nyata $(\mathrm{p}>0,05)$.

- Nilai rata-rata yang diikuti huruf yang sama pada baris yang sama menunjukkan berbeda tidak nyata $(\mathrm{p}>0,05)$.

Hasil sidik ragam menunjukkan bahwa interaksi antara suhu dan lama waktu pengeringan berpengaruh sangat nyata $(\mathrm{P}<0,01)$ terhadap aktivitas antioksidan teh herbal bunga telang. Nilai rata-rata aktivitas antioksidan berdasarkan nilai $\mathrm{IC}_{50}$ terendah terdapat pada perlakuan T1W3 (suhu pengeringan $50^{\circ} \mathrm{C}$ dan waktu 4 jam) yaitu sebesar 128,25 ppm, sedangkan nilai ratarata tertinggi terdapat pada perlakuan $\mathrm{T} 3 \mathrm{~W} 3$ (suhu pengeringan $70^{\circ} \mathrm{C}$ dan lama waktu pengeringan 4 jam) yaitu sebesar 174,38 ppm tidak berbeda nyata dengan perlakuan T3W1 dan T3W2. Hasil penelitian menunjukkan pada suhu yang terlalu tinggi dan waktu yang lebih lama menghasilkan nilai IC 50 yang semakin tinggi. Nilai $\mathrm{IC}_{50}$ yang tinggi menunjukkan kemampuan antioksidan yang rendah, sebaliknya nilai $\mathrm{IC}_{50}$ yang rendah menunjukkan kemampuan antioksidan yang tinggi. Pernyataan tersebut diperkuat oleh penelitian Kusuma et al., (2019), bahwa semakin tinggi nilai IC $_{50}$ maka aktivitas antioksidannya semakin rendah.
Penelitian yang dilakukan oleh Rusnayanti (2018) menyatakan aktivitas antioksidan akan turun apabila suhu pengeringan dan lama pengeringan terlalu tinggi. Hal ini disebabkan karena suhu pemanasan yang semakin tinggi dan waktu yang semakin lama mengakibatkan senyawa metabolit sekunder yang bertindak sebagai antioksidan menjadi rusak. Nilai $\mathrm{IC}_{50}$ yang rendah pada perlakuan T1W3 (suhu $50^{\circ} \mathrm{C}$ dan lama waktu 4 jam) sejalan dengan tingginya nilai total fenol dan flavonoid teh herbal bunga telang. Perlakuan suhu $50^{\circ} \mathrm{C}$ dan waktu 4 jam lebih baik dibandingkan perlakuan waktu 3 jam dan 3,5 jam. Hal ini dapat disebabkan karena kadar air bahan yang masih cukup tinggi. Menurut Pramono (2006) dalam Annisa (2019) bahan dengan kandungan air yang cukup tinggi mudah mengalami kerusakan sehingga aktivitas antioksidan tidak dapat dilihat. Selain itu kadar air yang cukup tinggi dalam bahan mendorong beberapa enzim melakukan aktivitasnya mengubah kandungan kimia bahan menjadi produk lain. Nilai $\mathrm{IC}_{50}$ pada 
teh herbal bunga telang perlakuan terbaik (T1W3) dapat digolongkan sebagai antioksidan sedang (100-150 ppm), dimana antioksidan sangat kuat (<50 ppm), kuat (50100) ppm, lemah (150-200 ppm), dan sangat lemah (>200 ppm).

\section{Uji warna dengan color reader}

Nilai rata-rata uji warna dengan color reader dapat dilihat pada Tabel 7.

Hasil sidik ragam menunjukkan bahwa interaksi antara suhu dan lama pengeringan berpengaruh sangat nyata $(\mathrm{P}<0,01)$ terhadap

Tabel 7. Nilai rata-rata uji warna dengan color reader

\begin{tabular}{|c|c|c|c|c|}
\hline \multirow{2}{*}{ CIE L*ab } & \multirow{2}{*}{ Suhu $(\mathrm{T})$} & \multicolumn{3}{|c|}{ Lama Pengeringan (W) } \\
\hline & & 3 jam (W1) & 3,5 jam (W2) & 4 jam (W3) \\
\hline \multirow{6}{*}{ Nilai L } & & $11,37 \mathrm{~B}$ & $7,86 \mathrm{~A}$ & $7,75 \mathrm{~A}$ \\
\hline & $50^{\circ} \mathrm{C}(\mathrm{T} 1)$ & $\mathrm{b}$ & $\mathrm{a}$ & $\mathrm{a}$ \\
\hline & & $6,42 \mathrm{~A}$ & $13,87 \mathrm{~B}$ & $14,66 \mathrm{~B}$ \\
\hline & $60^{\circ} \mathrm{C}(\mathrm{T} 2)$ & $\mathrm{a}$ & $\mathrm{b}$ & $\mathrm{c}$ \\
\hline & & $16,25 \mathrm{C}$ & $19,31 \mathrm{C}$ & $21,76 \mathrm{C}$ \\
\hline & $70^{\circ} \mathrm{C}(\mathrm{T} 3)$ & a & $\mathrm{b}$ & $\mathrm{c}$ \\
\hline \multirow{6}{*}{ Nilai a* } & & $-4,14 \mathrm{~B}$ & $-3,34 \mathrm{C}$ & $-1,88 \mathrm{C}$ \\
\hline & $50^{\circ} \mathrm{C}(\mathrm{T} 1)$ & a & b & $\mathrm{c}$ \\
\hline & & $-1,79 \mathrm{C}$ & $-8,33 \mathrm{~B}$ & $-6,58 \mathrm{~B}$ \\
\hline & $60^{\circ} \mathrm{C}(\mathrm{T} 2)$ & $\mathrm{b}$ & a & $\mathrm{a}$ \\
\hline & & $-9,75 \mathrm{~A}$ & $-9,15 \mathrm{~A}$ & $-16,67 \mathrm{~A}$ \\
\hline & $70^{\circ} \mathrm{C}(\mathrm{T} 3)$ & $\mathrm{b}$ & $\mathrm{b}$ & a \\
\hline \multirow{6}{*}{ Nilai b* } & & $-8,34 \mathrm{~B}$ & $-11,56 \mathrm{~A}$ & $-11,78 \mathrm{~A}$ \\
\hline & $50^{\circ} \mathrm{C}(\mathrm{T} 1)$ & $\mathrm{b}$ & $\mathrm{a}$ & $\mathrm{a}$ \\
\hline & & $-11,84 \mathrm{~A}$ & $-7,53 \mathrm{~A}$ & $-7,77 \mathrm{~A}$ \\
\hline & $60^{\circ} \mathrm{C}(\mathrm{T} 2)$ & a & $\mathrm{b}$ & $\mathrm{b}$ \\
\hline & & $-6,52 \mathrm{C}$ & $-3,49 \mathrm{~B}$ & $-2,27 \mathrm{~B}$ \\
\hline & $70^{\circ} \mathrm{C}(\mathrm{T} 3)$ & a & $\mathrm{b}$ & $\mathrm{c}$ \\
\hline
\end{tabular}

Keterangan: - Nilai rata-rata yang diikuti huruf yang sama pada kolom yang sama menunjukkan berbeda tidak nyata $(\mathrm{p}>0,05)$.

- Nilai rata-rata yang diikuti huruf yang sama pada baris yang sama menunjukkan berbeda tidak nyata $(p>0,05)$.

nilai L*ab teh herbal bunga telang. Nilai L* dinyatakan sebagai tingkat kecerahan, nilai $\mathrm{a}^{*}$ menunjukkan intensitas warna merah (nilai+) dan hijau (nilai-), dan nilai $b^{*}$ menunjukkan intensitas warna kuning (nilai+) dan biru (nilai-). Tabel 7 menunjukkan nilai rata-rata $\mathrm{L}$ tertinggi terdapat pada perlakuan T3W3 sebesar 21.76 dan nilai $\mathrm{L}$ terendah terdapat pada perlakuan T2W1 sebesar 6,42 . Nilai L yang semakin besar menunjukkan warna teh herbal bunga telang yang semakin cerah. Nilai L yang tinggi pada perlakuan T3W3 dapat disebabkan karena kandungan 
antosianinnya yang rendah sehingga warna yang dihasilkan lebih cerah dibandingkan perlakuan lainnya. Nilai rata-rata $a^{*}$ tertinggi terdapat pada perlakuan T2W1 sebesar -1,79 dan terendah pada perlakuan T3W3 sebesar -16,67. Hal ini menunjukkan perlakuan T3W3 cenderung lebih hijau

\section{Hasil uji sensoris teh herbal bunga telang}

Nilai rata-rata uji hedonik terhadap warna, aroma, rasa, penerimaan keseluruhan dan uji dibandingkan perlakuan lainnya. Nilai ratarata $b^{*}$ tertingi terdapat pada perlakuan T3W3 sebesar $-2,27$ dan terendah pada perlakuan T2W1 sebesar -11,84. Hal ini menunjukkan perlakuan T2W1 cenderung memiliki warna biru yang lebih gelap dibandingkan dengan perlakuan lain.

skoring rasa sepat minuman teh herbal bunga telang dapat dilihat pada Tabel 8 .

Tabel 8. Nilai rata - rata uji hedonik warna, aroma, rasa, penerimaan keseluruhan dan uji skoring rasa sepat teh herbal bunga telang

\begin{tabular}{cccccc}
\hline \multirow{2}{*}{ Perlakuan } & \multirow{2}{*}{ Warna } & \multirow{2}{*}{ Aroma } & \multicolumn{2}{c}{ Rasa } & Penerimaan \\
& & & Hedonik & Skoring & Keseluruhan \\
\hline T1W1 & $5,87 \pm 0,74 \mathrm{a}$ & $5,00 \pm 0,76 \mathrm{a}$ & $5,27 \pm 0,88 \mathrm{a}$ & $1,40 \pm 0,63 \mathrm{a}$ & $5,53 \pm 0,52 \mathrm{a}$ \\
T1W2 & $5,93 \pm 0,88 \mathrm{a}$ & $4,93 \pm 0,96 \mathrm{a}$ & $5,13 \pm 1,06 \mathrm{a}$ & $2,00 \pm 1,07 \mathrm{a}$ & $5,27 \pm 0,88 \mathrm{a}$ \\
T1W3 & $5,67 \pm 0,98 \mathrm{a}$ & $4,67 \pm 1,05 \mathrm{a}$ & $5,53 \pm 0,92 \mathrm{a}$ & $1,53 \pm 0,64 \mathrm{a}$ & $5,47 \pm 1,36 \mathrm{a}$ \\
T2W1 & $5,73 \pm 0,80 \mathrm{a}$ & $4,93 \pm 1,16 \mathrm{a}$ & $5,20 \pm 0,94 \mathrm{a}$ & $1,73 \pm 0,80 \mathrm{a}$ & $5,60 \pm 0,74 \mathrm{a}$ \\
T2W2 & $5,67 \pm 0,72 \mathrm{a}$ & $5,07 \pm 0,96 \mathrm{a}$ & $5,13 \pm 0,92 \mathrm{a}$ & $1,73 \pm 0,96 \mathrm{a}$ & $5,40 \pm 0,74 \mathrm{a}$ \\
T2W3 & $5,80 \pm 0,86 \mathrm{a}$ & $5,20 \pm 1,08 \mathrm{a}$ & $5,20 \pm 0,94 \mathrm{a}$ & $1,80 \pm 1,01 \mathrm{a}$ & $5,27 \pm 0,88 \mathrm{a}$ \\
T3W1 & $5,47 \pm 1,13 \mathrm{a}$ & $5,13 \pm 1,06 \mathrm{a}$ & $5,07 \pm 1,03 \mathrm{a}$ & $1,80 \pm 0,86 \mathrm{a}$ & $5,00 \pm 1,25 \mathrm{a}$ \\
T3W2 & $5,73 \pm 0,80 \mathrm{a}$ & $4,73 \pm 1,22 \mathrm{a}$ & $4,93 \pm 1,03 \mathrm{a}$ & $1,73 \pm 1,03 \mathrm{a}$ & $5,40 \pm 1,12 \mathrm{a}$ \\
T3W3 & $5,93 \pm 0,70 \mathrm{a}$ & $5,40 \pm 0,91 \mathrm{a}$ & $5,13 \pm 1,13 \mathrm{a}$ & $1,87 \pm 0,83 \mathrm{a}$ & $5,40 \pm 0,91 \mathrm{a}$ \\
\hline
\end{tabular}

Keterangan: - Nilai rata-rata yang diikuti huruf yang sama pada kolom yang sama menunjukkan berbeda tidak nyata $(\mathrm{p}>0,05)$.

- Nilai hedonik 1$)=$ sangat tidak suka, 2$)=$ tidak suka, 3$)=$ agak tidak suka, 4) $=$ biasa, 5) = agak suka, 6) $=$ suka, 7) $=$ sangat suka.

1. Warna

- Nilai skoring rasa 1$)=$ tidak sepat, 2) = kurang sepat, 3) = agak sepat, 4) = sepat, $5)=$ sangat sepat.

Perlakuan suhu dan lama pengeringan berpengaruh tidak nyata $(\mathrm{P}>0,05)$ terhadap warna (uji hedonik) minuman teh herbal bunga telang. Tabel 8 menunjukkan warna teh herbal bunga telang dapat diterima dengan kriteria suka.

\section{Aroma}

Hasil sidik ragam menunjukkan bahwa perlakuan suhu dan lama pengeringan berpengaruh tidak nyata $(\mathrm{P}>0,05)$ terhadap uji hedonik aroma minuman teh herbal bunga telang. Tabel 8 menunjukkan aroma minuman teh herbal bunga telang diterima dengan kriteria agak suka.

\section{Rasa}

Hasil sidik ragam menunjukkan bahwa perlakuan suhu dan waktu pengeringan berpengaruh tidak nyata $(\mathrm{P}>0,05)$ terhadap uji hedonik rasa minuman teh herbal bunga 
Telang dengan kriteria penerimaan agak suka sampai dengan suka. Pada uji skoring rasa, perlakuan suhu dan lama pengeringan berpengaruh tidak nyata $(\mathrm{P}>0,05)$ dengan kriteria kurang sepat.

4. Penerimaan keseluruhan

Hasil sidik ragam menunjukkan bahwa perlakuan suhu dan waktu pengeringan berpengaruh tidak nyata $(\mathrm{P}>0,05)$ terhadap penerimaan keseluruhan minuman teh herbal bunga telang. Tabel 7 menunjukkan penerimaan keseluruhan minuman teh herbal bunga telang diterima dengan kriteria agak suka sampai dengan suka.

\section{KESIMPULAN DAN SARAN}

\section{Kesimpulan}

Berdasarkan hasil penelitian ini dapat disimpulkan sebagai berikut:

1. Interaksi antara suhu dan lama pengeringan berpengaruh sangat nyata terhadap kadar air, kadar sari, total fenol, flavonoid, antosianin dan aktivitas antioksidan.

2. Perlakuan dengan suhu pengeringan $50^{\circ} \mathrm{C}$ dan lama waktu 4 jam merupakan perlakuan terbaik yang menghasilkan teh herbal dengan aktivitas antioksidan (berdasarkan nilai $\mathrm{IC}_{50}$ ) sebesar 128,25 ppm, kadar air 10,18\%, kadar sari 51,60 $\%$, total fenol 515,48 $\mathrm{mg} / 100 \mathrm{~g}$, flavonoid 23,99 mg/100g, antosianin $249,69 \mathrm{mg} / 100 \mathrm{~g}$, warna suka, aroma agak suka, rasa kurang sepat dan suka, penerimaan keseluruhan suka.

\section{Saran}

Berdasarkan penelitian yang telah dilakukan, disarankan sebagai berikut:

1. Melakukan analisis kimia hasil seduhan teh herbal bunga telang pada penelitianpenelitian selanjutnya.

2. Menggunakan metode pengeringan yang berbeda dalam mengolah teh herbal bunga telang untuk mendapatkan kadar air teh yang sesuai dengan SNI.

\section{DAFTAR PUSTAKA}

Adri, D. dan W. Hersoelistyorini. 2013. Aktivitas dan sifat organoleptik teh daun sirsak (Annona muricata Linn) berdasarkan variasi lama pengeringan. Jurnal Pangan dan Gizi. Vol. 04 (07): 1-12

Alnanda, R., D. Ulima, N. Merry, dan S. Purbaningsih 2017. Studi awal pemanfaatan kuntum Clitoria ternatea L. (kembang telang) sebagai pewarna alami makanan. Departemen Biologi, FMIPA UI, Kampus UI Depok, Jawa Barat.

Annisa. 2019. Pengaruh variasi suhu pengeringan terhadap aktivitas antioksidan teh daun kumis kucing (Orthosiphon spicatus B.B.S.). Penelitian Tugas Akhir Ilmu Pengetahuan Alam Universitas Sanata Dharma.

Budiasih, S. 2017. Kajian potensi farmakologis bunga telang (Clitoria ternatea). Prosiding Seminar Nasional Kimia UNY 2017 Sinergi Penelitian dan Pembelajaran untuk Mendukung Pengembangan Literasi

Kimia pada Era Global Ruang Seminar FMIPA UNY. 
Dewata, P., A. Sandhi, dan R. Widarta. 2017. Pengaruh suhu dan lama penyeduhan terhadap aktivitas antioksidan dan sifat sensoris teh herbal daun alpukat (Persea americana Mill). Jurnal Itepa A Vol. 6(2): 30-39.

Dwi, E.K. 2016. Pengaruh suhu dan lama pengeringan terhadap karakteristik teh herbal daun katuk (Sauropus Adrogynus L. Merr). Penelitian Tugas Akhir Teknologi Pangan Universitas Pasundan.

Fitrayana, C. 2014. Pengaruh lama dan suhu pengeringan terhadap karakteristik teh herbal pare (Momordica Charantia L). Tugas Akhir. Universitas Pasundan Bandung.

Hartiati, A., S. Mulyani dan D. Pusparini. 2009. Pengaruh preparasi bahan baku rosella dan waktu pemasakan terhadap aktivitas antioksidan sirup bunga rosella (Hibiscus sabdariffa L.). Jurnal Bali: Agrotekno,15(1): 2024.

Karina, A. 2008. Pemanfaatan jahe (Zingiberofficinale Rosc.) dan teh hijau (Camellia sinensis) dalam pembuatan selai rendah kalori dan sumber antioksidan. Skripsi. Fakultas Pertanian IPB. Bogor.

Kusuma, S., K. Putra, dan T. Darmayanti. 2019. Pengaruh suhu pengeringan terhadap aktivitas antioksidan teh herbal kulit kakao (Theobroma cacao L.). Jurnal Ilmu dan Teknologi Pangan Vol: 8(1): 85-93

Lee, M.P., R. Abdullah and K.L. Hung. 2011. Thermal degradation of blue anthocyanin extract of Clitoria ternatea flower. International Conference on Biotechnology and Food Science IPCBEE. Vol 7:49-53.

Muawanah, A. 2012. Penggunaan bunga kecombrang (Etlingera elatior) dalam proses formulasi permen jelly. Jakarta: Valensi, 2 (4): 526-527.

Parwata, I.N.A., N. Kusumawati dan N. Suryani. 2016. Pertumbuhan dan produksi hijauan kembang telang (Clitoria ternatea) pada berbagai level aplikasi pupuk bio-slurry. Journal of Tropical Animal Science 4(1): 142-155.

Pramitasari, D., R. Baskoro, G. Fauza. 2011. Penambahan ekstrak jahe dalam pembuatan susu kedelai bubuk instan dengan metode spray drying: komposisi kimia, sifat sensoris dan aktivitas antioksidan. Jurnal Biofarmasi Vol. 9(1): 17-25.

Rindy, P. 2017. Pengaruh perbandingan teh herbal daun binahong (Anredera cordifolia Ten Steenis) dengan daun teh (Camellia sinensis) dan suhu pengeringan terhadap karakteristik teh herbal. Skripsi. Program Studi Teknologi Pangan Fakultas Teknik Universitas Pasundan.

Rohkyani, I. 2015. Aktivitas antioksidan dan uji organoleptik teh celup batang dan bunga kecombrang pada variasi suhu pengeringan. Skripsi. Program Studi Pendidikan Biologi Fakultas Keguruan dan Ilmu Pendidikan Universitas Muhammadiyah Surakarta.

Rusnayanti. 2018. Pengaruh suhu dan lama pengeringan terhadap mutu teh hijau daun kakao (Theobroma cacao L.). Artikel Ilmiah Teknologi Pangan dan Agroindustri Universitas Mataram.

Siti, A., A. Alamsyah, dan Y. Sulastri. 2018. Beberapa pengaruh lama pengeringan terhadap beberapa kompenen mutu teh herbal kulit melinjo (Gnetum gnemon L.). Artikel Ilmiah Fakultas Teknologi Pangan dan Agroindustri Universitas Mataram.

Zussiva, A., B. Karina dan S. Budiyanti. 2012. Ekstraksi dan analisis zat warna biru (anthosianin) dari bunga telang (Clitoria ternatea) sebagai pewarna alami. Jurnal Teknologi Kimia dan Industri, Vol 1(1): 356-365. 